\title{
Isolation and Identification of Salmonella species from the table eggs in Sulaimani province
}

\author{
E. D. Arif
}

Coll. of Vet. Med../ Univ, of Sulaimani

\section{Abstract}

Out of 150 eggs were collected randomly as (local egg 50 and imported egg 100) from different markets of Sulaimani city, during the period from October 2009 to June 2010, Three (3\%) of imported eggs were found contaminated with Salmonella. Three different Salmonella serotypes were identified including; Salmonella typhimurium (one strain), Salmonella ohio (one strain) and Salmonella enteritidis (one strain) which represented $1 \%$ for each.

\section{Introduction}

Eggs are nutritious foods and they form an important part of the human diet. Consuming eggs, however, has been associated with negative health impacts. Eggs that are improperly handled can be a source of food borne diseases, such as Salmonellosis. Salmonellosis is a leading food borne disease worldwide. A Wide range of foods has been implicated in such disease. However, foods of animal origin, especially poultry and poultry products, including eggs, have been consistently implicated in sporadic cases and outbreaks of human Salmonellosis $(6,11,13)$. Poultry are widely acknowledged to be a reservoir for Salmonella.Egg contents may be contaminated with Salmonellae by 2 routes: Transovarian (vertical transmission) or trans-shell (horizontal transmission).In vertical transmission, Salmonella are introduced from infected reproductive tissues to eggs prior to shell formation. Salmonella serotypes associated with

\section{Material and methods}

A total of 150 eggs were collected randomly from local markets in Sulaimani city during the period from October 2009 to June 2010.The eggs were directly transferred by refrigerated containers to laboratory and analyzed immediately without further storage. The egg samples were submitted for the bacteriological investigation. Each sample consisted of 10 eggs. The liquid contents of these eggs were separated and the shell were put into a sterile plastic bag and crushed.A after that poultry reproductive tissues that are of public health concern include Salmonella enteritidis, Salmonella typhimurium and Salmonella Heidelberg (4,9).Among the different serotypes, Salmonella enteritidis may be better able to achieve invasion, and as a consequence, may be found more frequently in reproductive tissues $(14,8)$.Horizontal transmission is usually derived from fecal contamination on the egg shell. It also includes contamination through environmental vectors, such as farmers, pets and rodents. Many different serotypes of the genus Salmonella can be involved. They may be able to contaminate egg contents by migration through the egg shell and membranes. Such a route is facilitated by moist egg shells, storage at ambient temperature and shell damage $(1,7)$. The aim of this study was to investigate the contamination ratio of table eggs with Salmonella species in Sulaimani City.

the crushed shell were added to a flask containing $225 \mathrm{ml}$ buffered peptone waters. Twenty-five $\mathrm{ml}$ homogenized liquids (White and yolk liquids) were added into another flask containing the same amount of buffered peptone waters. The flasks were incubated at 37 c. Five $\mathrm{ml}$ pr-enriched cultures were transferred to flasks containing $45 \mathrm{ml}$ tetrathionate broth (Selective Enrichment) and incubated for $24 \mathrm{~h}$ at $42 \stackrel{\mathrm{c}}{\mathrm{c}}$. After the $24 \mathrm{~h}$ incubation the tetrathionate broth cultures was streaked 
onto Salmonella Shigella agar and Brilliants green agar (Selective media).Following that, the suspected Salmonella colonies were transferred simultaneously to Kligler and Urea agar base tubes by stabbing the butt and streaking the slope, and incubated for $24 \mathrm{~h}$ at $37^{\circ} \mathrm{c}$. (2) Slide agglutination test

\section{Result and Discussion}

Out of the 150 eggs that were collected from different markets of Sulaimani city, three eggs (3\%) of imported turkey eggs were found to be contaminated with Salmonella while non were isolated from local eggs. The isolated strains were Salmonella typhimurium (one strain) Salmonella Ohio (one strain) and Salmonella enteritidis (one strain) which represented $1 \%$ for each.Row egg shell and its contents are known to be source of Salmonella (12) but in this study the isolated Salmonella species were isolated from egg shell. This indicates that the eggs were contaminated either during its lays through the contaminated cloacae or from direct contact with contaminated nest, litter ,trays, and transport boxes after collection and delivered to markets. This finding that means the eggs were may be not cleaned by brush. This result is in agreement with study of Barbour and Nabbout (3). The low percentage of contaminated eggs may be at tribute to the time of sampling because this study was performed in winter from October to June. The eggs used in this study included local eggs and imported eggs from Turkey; the contaminated egg was imported from Turkey which confirms the idea that contamination was during transportation and delivery the market. was performed for the tubes showing reactions typical of Salmonella, using somatic polyvalent Salmonella serum (5). The isolated Salmonella strains were undergone serotyping at the Institute of Public Health, Baghdad.
Salmonella enteritidis is known to have unusual ability to colonize in ovarian tissues of hens and transmitted vertically to be presents within the contents of intact shell eggs; therefore it is not surprising that Salmonella enteritidis was isolated from shells and contents. (14). Food poisoning risks may occur because the organisms present on egg shell may contaminate the egg contents at breaking and or through washing of the shell which facilitates the entrance of bacteria through the shell pores to the contents and poor personal hygiene of food handling may cause food poisoning to consumers.Salmonella typhimurium is known to be able to infect the ovaries of laying hens and to cause transovarian transmission of infection but in contaminated the shell it may have been caused by contaminated wit fecal matter through egg passing in cloacae. Salmonella typhimurium particularly is a signification public health concern especially among infants. (7, 10) This study recommends following a good biosecurity roles in collection, handling and a sanitized procedure in egg cleaning from dirt by hard brush in farms and examination of transported boxes of eggs and vehicles that transported boxes. 


\section{References}

1.Advisory Committee on the Microbiological Safety of Food. (2001).Second Report on Salmonella in Eggs. London: The Stationery Office.

2. Altin, T.; Bizena, B.; Kapllan, S. and Elvira, B. (1999). Occurrence of Salmonella spp. In imported eggs into Albania. J. Food Microbiology. 49: 169-171.

3. Barbour, E.K and Nabbut, N.H. (1981). Isolation of Salmonella and some other potential pathogens from Two Chicken breeding farms in Saudi Arabia. Avian Diseases. Vol .26 No.2: 234-244

4. Barnhart, H.M.; Dreesen, D.W.; Bastien, R. and Pancorbo, O.C. (1991). Prevalence of Salmonella enteritidis and other serovars in ovaries of layer hens at time of slaughter. J .Food Protect, 54: 488491.

5. Ewing, W.H. (1986) .The genus Salmonella. In: Ewing WH, ed. Edwards and Ewing's identification of Enterobacteriaceae. 4th Ed. New York. Elsevier, 181-245.

6. Humphrey, T.; Baskerville, A.; Chart, H. and Rowe, B. (1989). Infection of egg laying hens with Salmonella enteritidis PT4 by oral inoculation.Vet.Rec, 125:5315328.

7. Poppe, C.; Duncan, C. and Mazzocco, A. (1998). Salmonella contamination of hatching and table eggs: A comparison.Can.J.Vet.Res, 62:191-198

8. Promosopone, B.; Morishita, T.Y.; Aye, P.P.; Cobb, C.W.; Veldkamp, A. and Clifford, J.R. (1998). Evaluation of an avian-specific antibiotic on the colonization of Salmonella typhimurium in broiler. J. Food Prot., 61: 176-180.

9. ICMSF. (1996). Eggs and Egg Products. In: Micro-organisms in Foods 6: Microbial Ecology of Food Commodities. London: Chapman \& Hall., P.475-520.

10. Levi ne, W.C.; Buchler, J.W.; Bean, N.H. and Tauxe, R.V. (1991). Epidemiology of nontyphoidal Salmonella bacteraemia during the human immunodeficiency virus epidemic. J. Inf. Dis., 164: 81-87.

11. Radford, S. A. and Board, R.G. (1993).Review: Fat of pathogens in home-made mayonnaise and related products. Food Microbiol, 10:248-261

12. Zancan, F.T.; Junior; B. A.; Fernandes, S.A and Gama, N.M (2000). Salmonella spp. investigation in transport boxes of day-old birds. Brazilian J. Microbiol. , 31:230232

13. Telzak, E.; budnick, L.; Zweig, M.; Blum, S.; Shayegani, M.; Benson, C.; and Schultz, S. (1990). Nosocomial outbreak of Salmonella enteritidis infection due to the consumption of raw eggs. New Eng. J. Med., 323: 394-397.

14. Timoney, J.F; Shivaprasad, H.L; Baker, R.C and Rowe, B. (1989). Egg transmission after infection of hens with Salmonella enteritidis phage type 4. Vet Rec., 125: 600-601. 


\section{عزل وتمييز انواع السالمونيلا من بيض المائدة في مدينة السليمانية}

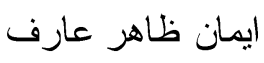

كلية الطب البيطري/ جامعة السليمانية

الخلاصة

اجريت هذه الدراسة على مئة وخسون عينة عشو ائية من بيض المائدة بواقع (محليه 50 بيضه و مستوردة

100 بيضد) جمعت من اسواق مدينة السليمانية خلال الفترة من شهرنترين الاول 2009 2لغولغاية شهر حزيرن

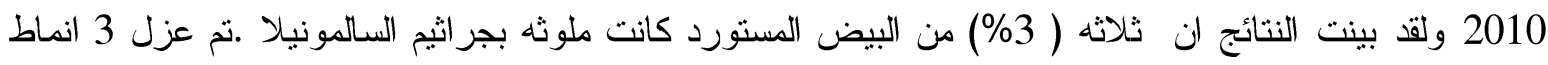
مصلية من جراثيم السالمونيلا شملت كل من Salmonella typhimurium ( عزلة واحدة) Sallam ohio (عزلة واحدة) و Salmonella enteritidis (عزلة واحدة ) وبنسبة 1\% كل كل نوع . 